Open Access

\title{
Aerobic exercise training enhances the in vivo cholesterol trafficking from macrophages to the liver independently of changes in the expression of genes involved in lipid flux in macrophages and aorta
}

Paula Ramos Pinto ${ }^{1 \dagger}$, Débora Dias Ferraretto Moura Rocco ${ }^{1+}$, Ligia Shimabukuro Okuda ${ }^{1}$, Adriana Machado-Lima ${ }^{1}$, Gabriela Castilho', Karolline Santana da Silva', Diego Juvenal Gomes', Raphael de Souza Pinto', Rodrigo Tallada Iborra', Guilherme da Silva Ferreira', Edna Regina Nakandakare', Ubiratan Fabres Machado², Maria Lucia Cardillo Correa-Giannella ${ }^{3}$, Sergio Catanozi ${ }^{1}$ and Marisa Passarellii ${ }^{*}$

\begin{abstract}
Background: Regular exercise prevents and regresses atherosclerosis by improving lipid metabolism and antioxidant defenses. Exercise ameliorates the reverse cholesterol transport (RCT), an antiatherogenic system that drives cholesterol from arterial macrophages to the liver for excretion into bile and feces. In this study we analyzed the role of aerobic exercise on the in vivo RCT and expression of genes and proteins involved in lipid flux and inflammation in peritoneal macrophages, aortic arch and liver from wild type mice.

Methods: Twelve-week-old male mice were divided into sedentary and trained groups. Exercise training was performed in a treadmill (15 m/min, 30 min/day, 5 days/week). Plasma lipids were determined by enzymatic methods and lipoprotein profile by fast protein liquid chromatography. After intraperitoneal injection of J774-macrophages the RCT was assessed by measuring the recovery of ${ }^{3} \mathrm{H}$-cholesterol in plasma, feces and liver. The expression of liver receptors was determined by immunoblot, macrophages and aortic mRNAs by qRT-PCR. ${ }^{14} \mathrm{C}$-cholesterol efflux mediated by apo A-I and $\mathrm{HDL}_{2}$ and the uptake of ${ }^{3} \mathrm{H}$-cholesteryl oleoyl ether $\left({ }^{3} \mathrm{H}\right.$-COE)-acetylated-LDL were determined in macrophages isolated from sedentary and trained animals $48 \mathrm{~h}$ after the last exercise session.

Results: Body weight, plasma lipids, lipoprotein profile, glucose and blood pressure were not modified by exercise training. A greater amount of ${ }^{3} \mathrm{H}$-cholesterol was recovered in plasma ( $24 \mathrm{~h}$ and $48 \mathrm{~h}$ ) and liver ( $48 \mathrm{~h}$ ) from trained animals in comparison to sedentary. No difference was found in ${ }^{3} \mathrm{H}$-cholesterol excreted in feces between trained and sedentary mice. The hepatic expression of scavenger receptor class B type I (SR-BI) and LDL receptor (B-E) was enhanced by exercise. We observed 2.8 and 1.7 fold rise, respectively, in LXR and Cyp7a mRNA in the liver of trained as compared to sedentary mice. Macrophage and aortic expression of genes involved in lipid efflux was not systematically changed by physical exercise. In agreement, ${ }^{14} \mathrm{C}$-cholestrol efflux and uptake of ${ }^{3} \mathrm{H}$-COE-acetylated-LDL by macrophages was similar between sedentary and trained animals.

(Continued on next page)
\end{abstract}

\footnotetext{
* Correspondence: mpassere@usp.br

${ }^{\dagger}$ Equal contributors

'Lipids Laboratory (LIM - 10), University of São Paulo Medical School, Av. Dr.

Arnaldo 455, room 3305, Sao Paulo, SP CEP 01246000, Brazil

Full list of author information is available at the end of the article
} 
(Continued from previous page)

Conclusion: Aerobic exercise in vivo accelerates the traffic of cholesterol from macrophages to the liver contributing to prevention and regression of atherosclerosis, independently of changes in macrophage and aorta gene expression.

Keywords: Atherosclerosis, HDL, Physical exercise, Reverse cholesterol transport, Macrophages

\section{Introduction}

Regular physical exercise improves lipid metabolism, blood pressure, insulin sensitivity, endothelial function and haemostatic factors, reducing the incidence of coronary heart disease independently of other changes in life style [1-7]. In animal models of atherosclerosis it has been shown that aerobic exercise training reduces the area of pre established atherosclerotic lesions, ameliorates plaque stability and improves mice survival rate $[8,9]$. These benefits can also be ascribed to the role of exercise in elevate antioxidant defenses in plasma and arterial wall, as well as, plasma HDL cholesterol levels.

HDL mediates the reverse cholesterol transport (RCT), an antiatherogenic system that drives cholesterol from the arterial wall to the liver assuring its excretion into feces. RCT is mediated by an orchestrated action of cholesteryl ester transfer protein (CETP), lipoprotein lipase, hepatic lipase, lecithin cholesterol acyltransferase (LCAT), ABC transporters (ABCA-1 and ABCG-1) and scavenger receptor class B, type I (SR-BI) [10].

By utilizing an in vivo measurement of the RCT, Meisser et al. (2010) did not demonstrate alteration in this system by utilizing a 2-week endurance voluntary exercise protocol [11]. Although, in the same animal model those authors (Meisser et al., 2010) found that a more prolonged exercise protocol enhanced biliary excretion of cholesterol which indicates a benefit in RCT [12]. Wei et al. (2005) showed enhanced expression of SR-BI and LDL-receptor mRNA levels in the liver of exercised mice, as an evidence for the improvement of the RCT by a 2-week aerobic exercise training protocol [13].

There is no evidence so far on the role played by aerobic exercise training - at the same volume/duration of that performed in studies showing atherosclerosis prevention or regression - in the RCT flow and in the expression of genes or levels of proteins that modulate this system. In this work, we analyzed the role of a 6-week well-controlled aerobic exercise training in the in vivo traffic of ${ }^{3} \mathrm{H}$-cholesterol from macrophages to plasma, liver and feces, the expression of genes and receptor levels involved in lipid flux in the liver, macrophages and aortic arch. The ability of macrophages isolated from trained and sedentary animals to export ${ }^{14} \mathrm{C}$-cholesterol to apo $\mathrm{A}-\mathrm{I}$ or $\mathrm{HDL}_{2}$ as well as the uptake of ${ }^{3} \mathrm{H}$-cholesteryl oleoil ether acetylated LDL were also analyzed. We demonstrated that independently of changes in macrophage and aortic arch gene expression, aerobic training improves macrophage ${ }^{3} \mathrm{H}$-cholesterol flux to the liver. This was related to a greater amount of SR-BI protein level and Cyp7a1 expression in the liver.

\section{Materials and methods}

Animals

C57BL/6N male mice (Taconic Inc, New York, USA) were fed regular chow ad libitum (Nuvilab-Nuvital, São Paulo, Brazil) with free access to water and were housed in conventional housing at $22 \pm 2{ }^{\circ} \mathrm{C}$ with a $12 \mathrm{~h}$ light/12 $\mathrm{h}$ dark cycle. Animal experiments were performed in accordance with protocols approved by the Institutional Animal Care and Research Advisory Committee (Hospital das Clinicas of the University of São Paulo Medical School - CAPPesq \# 773/06 and 441/11) and by the US National Institutes of Health Guidelines [14].

\section{Plasma lipid analysis}

Cholesterol concentration in all lipoprotein fractions was measured by enzymatic colorimetric kit (Roche Diagnostic, Brazil). HDL-c was determined at the final period only by the ratio: HDL cholesterol area/total cholesterol area. Total plasma cholesterol and triglycerides were determined by enzymatic techniques (Labtest, Brazil) and glucose by Accu Check Performa glucometer (Roche, Brazil). Lipoprotein profile was determined by fast protein liquid chromatography (FPLC) gel filtration on two Superose 6 columns.

\section{Blood pressure measurement}

Systolic blood pressure (BP) was assessed in conscious mice with a standard tail-cuff technique using an oscillometric method. Animals previously warmed for $12 \mathrm{~min}$ at $40^{\circ} \mathrm{C}$ were placed in a restrainer with the tail exiting through the rear hatch. BP measurements were considered only in the rested animal. After three successive days of mouse preconditioning to the measurement system, ten readings were carried out in two consecutive days and averaged to obtain mean values.

\section{Training protocol}

Before starting training, animals from both groups, sedentary and trained were submitted to running adaptation. Briefly, animals were placed in a treadmill for $10 \mathrm{~min}$ at $8 \mathrm{~m} / \mathrm{min}$ with a progressive increment up to $15 \mathrm{~m} / \mathrm{mim}$. Animals that were not able to keep running were excluded (8.1\% of exclusion). 
Twelve-week-old animals were submitted to a 6-week monitored aerobic exercise training protocol performed on a treadmill (WEG CFW-08, São Carlos, Brazil) at $15 \mathrm{~m} / \mathrm{min}$ during 30-min sessions, 5 times a week. A control group was kept sedentary during all period. Exercise sessions were carried out in the late afternoon. Animals reached $15 \mathrm{~m} / \mathrm{min}$ after the first week of training animal at $12 \mathrm{~m} / \mathrm{min}$.

\section{Measurement of the in vivo RCT}

J774 macrophages were incubated for $48 \mathrm{~h}$ in labeling media containing $50 \mu \mathrm{g} / \mathrm{mL}$ acetylated low-density lipoprotein (LDL) and $5 \mu \mathrm{Ci} / \mathrm{mL}^{3} \mathrm{H}$-cholesterol. After $24 \mathrm{~h}$ incubation in DMEM containing fatty acid free albumin allowing the equilibratium of intracellular cholesterol pools, cells were washed, centrifuged and resuspended in PBS. Cell viability was superior to $98 \%$ according to Trypan blue exclusion. Around $96 \%$ of intracelular cholesterol was in free form as assessed by thin layer chromatography.

A hundred microliters of cell suspension $(\sim 3.2 \times$ $\left.10^{6} \mathrm{dpm}\right)$ was injected into sedentary and trained mouse peritoneal cavity after $48 \mathrm{~h}$ of the last exercise session. Following, animals were individually housed in metabolic cages with free access to food and water to have blood drawn from the tail vein and feces collected $24 \mathrm{~h}$ and $48 \mathrm{~h}$ after ${ }^{3} \mathrm{H}$-cholesterol-labeled cells injection into peritoneal cavity.

Blood was centrifuged (1,500 rpm, $\left.20 \mathrm{~min}, 4{ }^{\circ} \mathrm{C}\right)$ and the radioactivity determined. Forty eight hours after the injection, animals were euthanized and the liver, spleen, lung, heart, kidneys and adrenal glands removed. After washing with cold $0.9 \% \mathrm{NaCl}$ solution the organs were dried and weighed. Organs and feces were stored at $-70^{\circ}$ until processing. Briefly, they were mixed with a $2: 1$ (v:v) chloroform/methanol solution [15] and stored at $4{ }^{\circ} \mathrm{C}$ overnight for lipid extraction. The radioactivity was determined after lipid layer evaporation under nitrogen flow. The recuperation of ${ }^{3} \mathrm{H}$-cholesterol in plasma, organs and feces was expressed as percentages of total dose (dpm) injected per gram of sample (liver or feces) or plasma volume (mL). The recovery of radioactivity in spleen, lung, heart, kidney and adrenal glands was minimal (data not shown).

\section{Lipoproteins isolation and LDL acetylation and labelling}

Procedures with humans were in accordance with the Declaration of Helsinki. All blood donors had signed an informed written consent form previously approved by The Ethical Committee for Human Research Protocols of the Hospital das Clinicas, University of São Paulo Medical School (CAPPesq \# 773/06 and 441/11). Low density lipoprotein (LDL, $\mathrm{d}=1,019-1,063 \mathrm{~g} / \mathrm{mL}$ ) and high density lipoprotein subfraction $2\left(\mathrm{HDL}_{2}, \mathrm{~d}=1,063-1,125 \mathrm{~g} / \mathrm{mL}\right)$ were isolated from healthy plasma donors by sequential ultracentrifugation and further purified by discontinuous gradient ultracentrifugation. Protein content was determined by the Lowry procedure [16]. LDL acetylation was performed according to Basu et al. [17]. After extensive dialysis against ethylenediaminetetraacetic phosphatebuffered saline (EDTA-PBS), acetylated LDL (AcLDL) and HDL were maintained sterile at $4{ }^{\circ} \mathrm{C}$ under nitrogen atmosphere and used within a month. For some experiments LDL was labelled with ${ }^{3} \mathrm{H}$-cholesteryl oleoyl ether $\left({ }^{3} \mathrm{H}-\mathrm{COE}\right)$ according to Terpstra et al. [18].

\section{Western blotting analysis}

Protein lysates were obtained by tissue homogenates in Polytron (MA099 Potter Unit, Marcone Equip., São Paulo, Brazil) by using buffer containing $20 \mathrm{mM}$ Hepes, $150 \mathrm{mM} \mathrm{NaCl}, 10 \%$ glycerol, 1 \% triton, $1 \mathrm{mM}$ EDTA, $1.5 \mathrm{mM} \mathrm{MgCl}_{2}$ and protease inhibitors. An aliquot of supernatant was obtained after centrifugation and dissolved in SDS-glycerol. Equal amounts of sample protein were applied into a polyacrylamide gel and immunoblotting performed for SR-BI, LXR and the LDL receptor by using anti-SR-BI 1:1,000, anti-LXR $1: 1,000$ (Novus Biologicals, Inc., Littleton, CO, USA), and anti-LDL receptor 1:1,000 (Santa Cruz Biotechnology Inc, USA). Membranes were incubated with HRP-conjugated antibody and reacted against ECL (Super Signal West Pico Chemiluminescent substract, Pierce, Rockford, IL, EUA). Nitrocellulose membrane stripping was done by washing with $\mathrm{NaOH} 0.8 \mathrm{mM}$. The difference between the bands was analyzed in pixels using the JX-330 Color Image Scanner (Sharp ${ }^{\circledR}$ ) and ImageMaster software (Pharmacia Biotech). Results are expressed as arbitrary units corrected per $\beta$-actin (anti $\beta$-actin 1:1,000, Fitzgerald Industries International, Inc., Concord, MA). $\beta$-actin was utilized as a control and Ponceau staining of nitrocellulose membranes was also implemented to assure equal protein loading.

\section{Gene expression analysis}

Mice were euthanized in $\mathrm{CO}_{2}$ chamber and macrophages were harvested from peritoneal cavity immediately $(0 \mathrm{~h})$ or $48 \mathrm{~h}$ after the last session of exercise. Following, mice were transcardially perfused under low-pressure, with a $0.9 \%$ $\mathrm{NaCl}$ cold solution and then, aortic arch and liver were excised in the fresh state and preserved in liquid nitrogen as far as analysis. RNA was isolated from tissues and macrophages by using Trizol (Invitrogen Life Technologies, Carlsbad, CA, USA). The cDNA was synthetized from $100 \mathrm{ng}$ of total RNA using the High Capacity RNA-tocDNA kit (Applied Biosystems). Real-time PCR was performed using Gene Expression Master Mix (Applied Biosystems). The following TaqMan Gene Expression Assays were used in the Step One Plus Real Time PCR System (Applied Biosystems): Cyp7a1 - Mm00484150_m1, Cyp27a1 - Mm00470430_m1, Abca1 - Mm00442646_m1, 
Table 1 Body weight, plasma lipids, glucose and blood pressure in trained and sedentary C57BL/6N mice

\begin{tabular}{lcccc}
\hline & & $\begin{array}{c}\text { Trained } \\
(n=66)\end{array}$ & $\begin{array}{l}\text { Sedentary } \\
(n=69)\end{array}$ & $p$ \\
\hline Body weight (g) & Basal & $26.1 \pm 3.4$ & $26.3 \pm 3.4$ & 0.736 \\
& Final & $27.4 \pm 3.6$ & $27.7 \pm 4.5$ & 0.645 \\
Total cholesterol (mg/dL) & Basal & $110 \pm 14$ & $107 \pm 20$ & 0.442 \\
& Final & $104 \pm 19$ & $109 \pm 20$ & 0.298 \\
Triglycerides (mg/dL) & Basal & $74 \pm 19$ & $70 \pm 21$ & 0.428 \\
& Final & $58 \pm 16$ & $58 \pm 13$ & 0.897 \\
Glucose (mg/dL) & Basal & $93 \pm 20$ & $95 \pm 19$ & 0.222 \\
& Final & $104 \pm 25$ & $106 \pm 23$ & 0.707 \\
Blood pressure (mmHg) & Basal & $84 \pm 10$ & $86 \pm 5$ & 0.222 \\
& Final & $76 \pm 7$ & $85 \pm 7$ & 0.007
\end{tabular}

Data are expressed as mean values \pm standard deviation.

Abcg1 Mm00437390_m1, Cd36 - Mm01135198_m1, Olr1 Mm00454586_m1, Scarb1 - Mm00450234_m1, Pparg Mm01184322_m1, Nr1h3 Mm01329744_g1, Nr1h2 Mm00437265_g1, Ccl2 - Mm00441242_m1, Tnf Mm00450234_m1, Il6 -Mm00450234_m1, Il10 - Mm 00450234_m1. The relative expression of each gene was measured with respect to the expression of the housekeeping genes Actb - Mm00607939_s1 (macrophages and liver) and Gapdh - Mm99999915_g1 (aortic arch), which were used as endogenous reference to correct for differences in the amount of total RNA added to the reaction. The relative quantification of gene expression was performed with StepOne Software 2.0 (Applied Biosystems) using the comparative cycle threshold $(\mathrm{Ct})\left(2^{-\Delta \Delta \mathrm{Ct}}\right)$ method $[19,20]$.

\section{Cholesterol efflux assay}

Macrophages were harvested from the peritoneal cavities of sedentary and trained mice and placed in PBS containing $1 \%$ penicillin-streptomycin and $4 \mathrm{mM} \mathrm{L}$-glutamine. Cells were collected immediately $(0 \mathrm{~h})$ and $48 \mathrm{~h}$ after the last exercise bout. Cells were cultivated in RPMI containing $10 \%$ fetal calf serum, $1 \%$ penicillin-streptomycin and $4 \mathrm{mM} \mathrm{L-}$ glutamine, and they were maintained in a $5 \% \mathrm{CO}_{2}$ incubator at $37{ }^{\circ} \mathrm{C}$ for $24 \mathrm{~h}$. After washing with PBS containing fatty acid free albumin (FAFA), cells were incubated with $50 \mu \mathrm{g} / \mathrm{mL}$ of acetylated LDL and $0.3 \mu \mathrm{Ci} / \mathrm{mL}$ of ${ }^{14} \mathrm{C}$-cholesterol for $30 \mathrm{~h}$. Cells were incubated with DMEM/FAFA for $24 \mathrm{~h}$ for equilibrate intracellular cholesterol pools and then incubated with $50 \mu \mathrm{g} / \mathrm{mL}$ of $\mathrm{HDL}_{2}$ protein or $30 \mu \mathrm{g}$ of apo A-I as cholesterol acceptors. Purified human apo A-I was gently provided by Dr. Shinji Yokoyama from Nutritional Health Science Research Center, Chubu University. Control cells were incubated with DMEM/FAFA alone. Cholesterol efflux was determined after $8 \mathrm{~h}$ and $24 \mathrm{~h}$. Medium was drawn and centrifuged at 1,500 rpm for $10 \mathrm{~min}$ to spin down cell debris, and the radioactivity was determined in the supernatant. Cell lipids were extracted three times with a hexane/ isopropanol mixture $(2: 1 ; \mathrm{v}: \mathrm{v})$, and the radioactivity was determined after solvent evaporation. Cell lysate was obtained after a two-hour incubation period with $0.2 \mathrm{~N}$ $\mathrm{NaOH}$ in order to measure protein concentration. The percentage of ${ }^{14} \mathrm{C}$-cholesterol efflux was calculated as $\left({ }^{14} \mathrm{C}\right.$-cholesterol in the medium $/{ }^{14} \mathrm{C}$-cholesterol in cells plus medium) $\times 100$. The difference between the efflux elicited by $\mathrm{HDL}_{2}$ or apo A-I plus albumin and that by albumin-enriched media alone results in the $\mathrm{HDL}_{2}$ and A-I-mediated efflux.

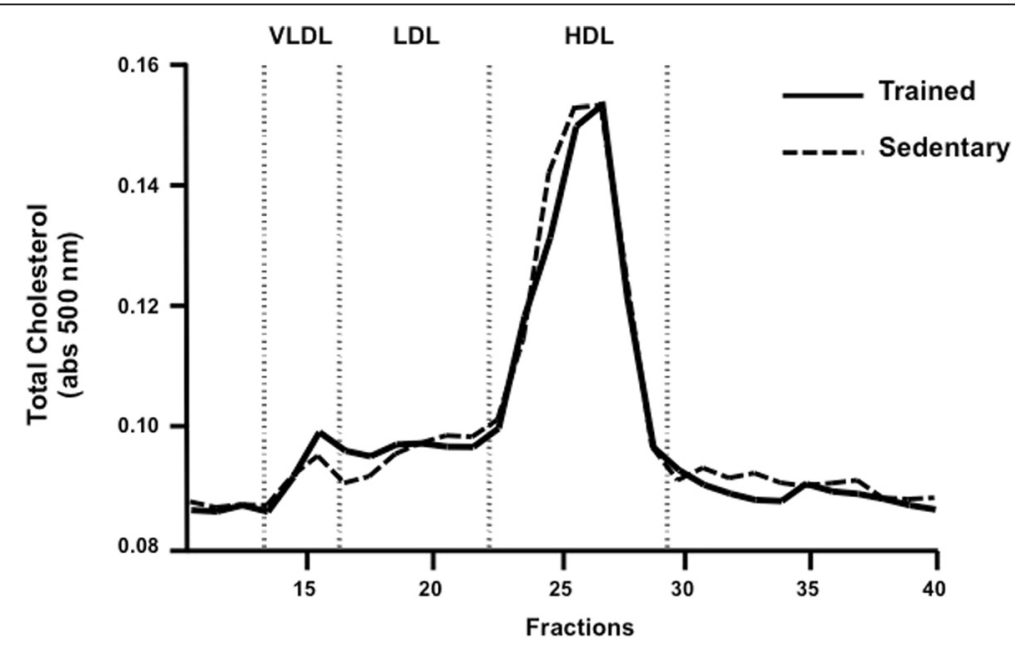

Fig. 1 Plasma Lipoprotein profile of trained and sedentary mice after training protocol. Plasma lipoproteins were isolated by fast protein liquid chromatography (FPLC), and total cholesterol was determined in all fractions using an enzymatic kit. Trained (filled line) and sedentary (dashed line) 
Uptake of acetylated LDL

Macrophages were incubated for $6 \mathrm{~h}$ in the presence of ${ }^{3} \mathrm{H}$ COE-acetylated LDL and LDL uptake ( $\mu \mathrm{g}$ of LDL/mg of cell protein) calculated after cell washing, solubilization with $0.2 \mathrm{~N} \mathrm{NaOH}$, radioactivity counting and cell protein determination.

\section{Statistical analysis}

Statistical analyses were performed using GraphPad Prism 5.0 software (GraphPad Prism, Inc., San Diego, CA). Unpaired Student' $t$ test was utilized to compare differences between groups. Summary data are reported as mean values \pm standard error or mean values \pm standard deviation as indicated. A p-value $<0.05$ was considered statistically significant.

\section{Results}

After six-week of aerobic exercise training, body weight, total plasma cholesterol, triglycerides and glucose concentration were not different between groups (Table 1). Similarly, plasma lipid profile assessed by FPLC was not changed by the aerobic exercise training (Fig. 1). Systolic blood pressure was reduced after exercise training (Table 1).

The distribution of ${ }^{3} \mathrm{H}$-cholesterol was analyzed in plasma and feces at $24 \mathrm{~h}$ and $48 \mathrm{~h}$ and in the liver at $48 \mathrm{~h}$ following the intraperitoneal injection of J774 macrophages enriched with acetylated LDL and radiolabeled cholesterol. In the trained mice a higher amount of ${ }^{3} \mathrm{H}$-cholesterol was recovered in plasma and liver compared to the sedentary group (Fig. 2a and b). However, the amount of ${ }^{3} \mathrm{H}$-cholesterol excreted into feces was similar between trained and sedentary mice (Fig. 2c). Total fecal mass (g) was similar between trained and sedentary groups (respectively $24 \mathrm{~h}$ : $0.78 \pm 0.1$ vs $0.84 \pm 0.3 ; 48$ h: $0.8 \pm 0.1$ vs $1.0 \pm 0.3$ ).

The expression of SR-BI was $60 \%$ enhanced in the liver of trained mice as compared to sedentary (Fig. 3). Also, a higher expression of hepatic LDL receptor was found in trained mice in comparison to sedentary animals (Fig. 4). Moreover, the expression of LXR was 2.8 fold elevated in the liver of trained compared to sedentary animals (Fig. 5). Aerobic exercise training raised the mRNA of Cyp7A1 although no changes were observed in Cyp27a1 mRNA expression (Fig. 6).

Peritoneal macrophages were isolated in order to investigate acute and chronic effects of exercise in gene expression. Among genes involved in LDL uptake by macrophages, $C d 36$ and Orl1 mRNA presented reduced levels at time $0 \mathrm{~h}$ in trained animals as compared to sedentary although no changes were further observed at $48 \mathrm{~h}$. On the contrary, Scarb1 mRNA levels were only enhanced in cells isolated after $48 \mathrm{~h}$ of exercise session. Genes related to cholesterol exportation to apo A-I and $\mathrm{HDL}_{2}$, respectively, $A b c a 1$ and $A b c g 1$ were acutely reduced by exercise $(0 \mathrm{~h})$

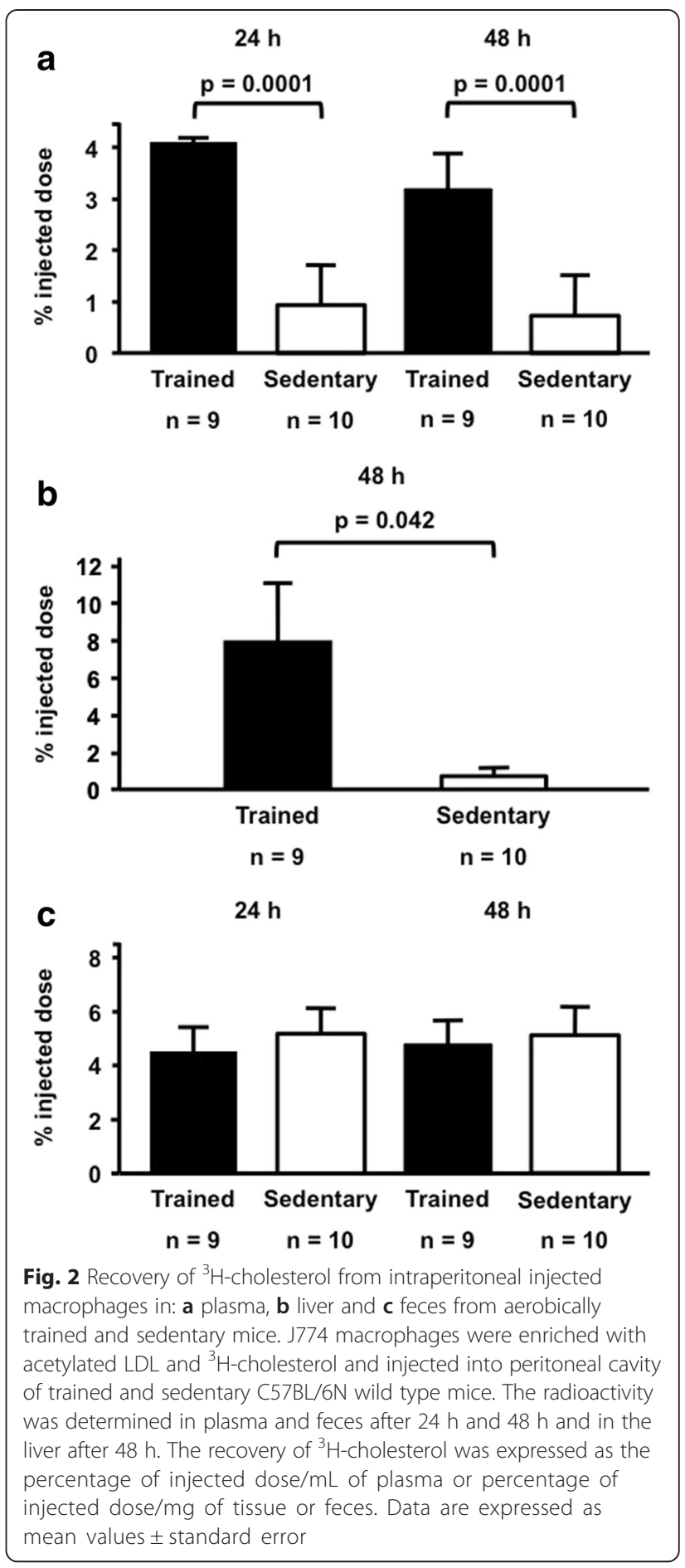

although changes were no longer observed in cells isolated after $48 \mathrm{~h}$. In agreement, transcriptional factors mRNA that modulate HDL receptors, such as Pparg, Nr1h3 and Nr1h2 were also reduced in macrophages isolated from trained animals immediately after the exercise session in comparison to sedentary animals. In cells isolated after $48 \mathrm{~h}$ no changes were observed between trained and sedentary groups (Fig. 7a and b). 


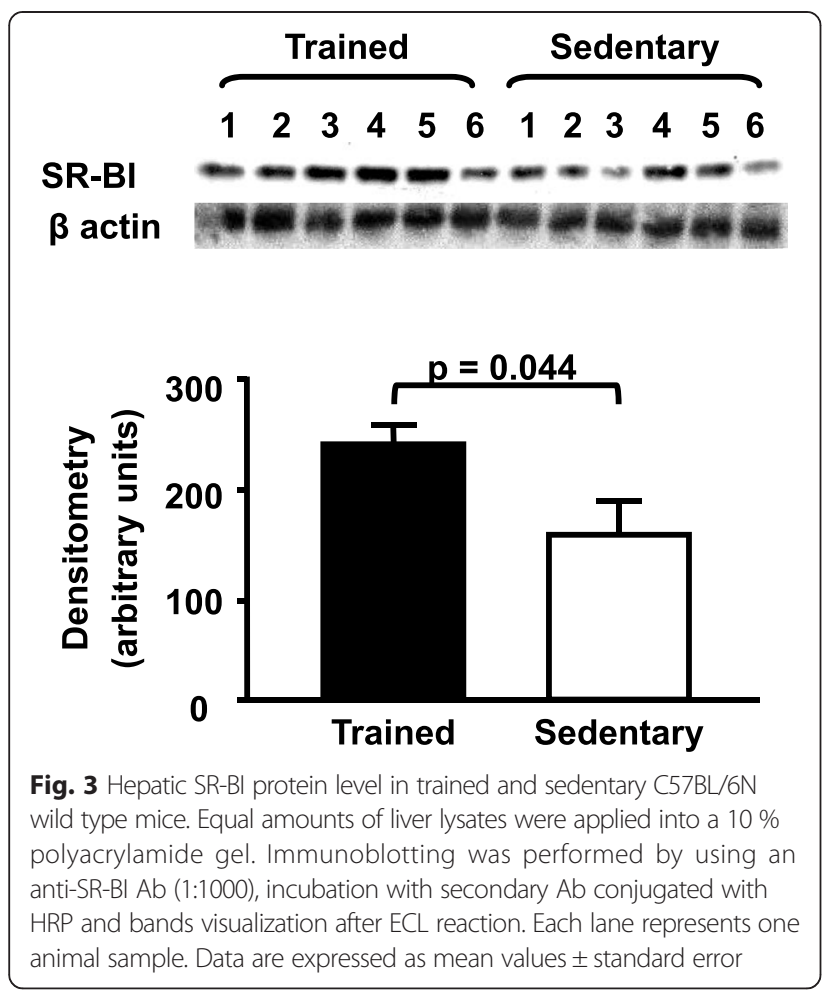

We also measured mRNA levels of genes that mediate inflammatory response that is known to modulate macrophage lipid metabolism. Tnf and $I l 10$ mRNAs were reduced in macrophages after exercise session $(0 \mathrm{~h})$ in trained animals as compared to sedentary mice. On the other hand,

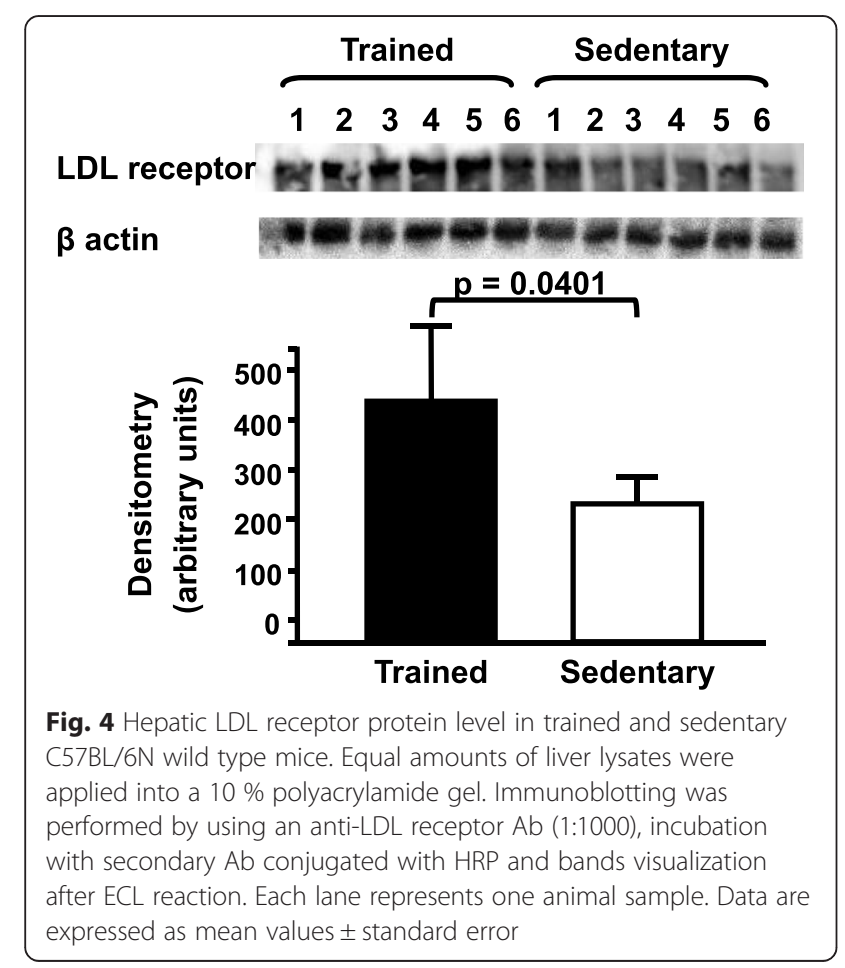

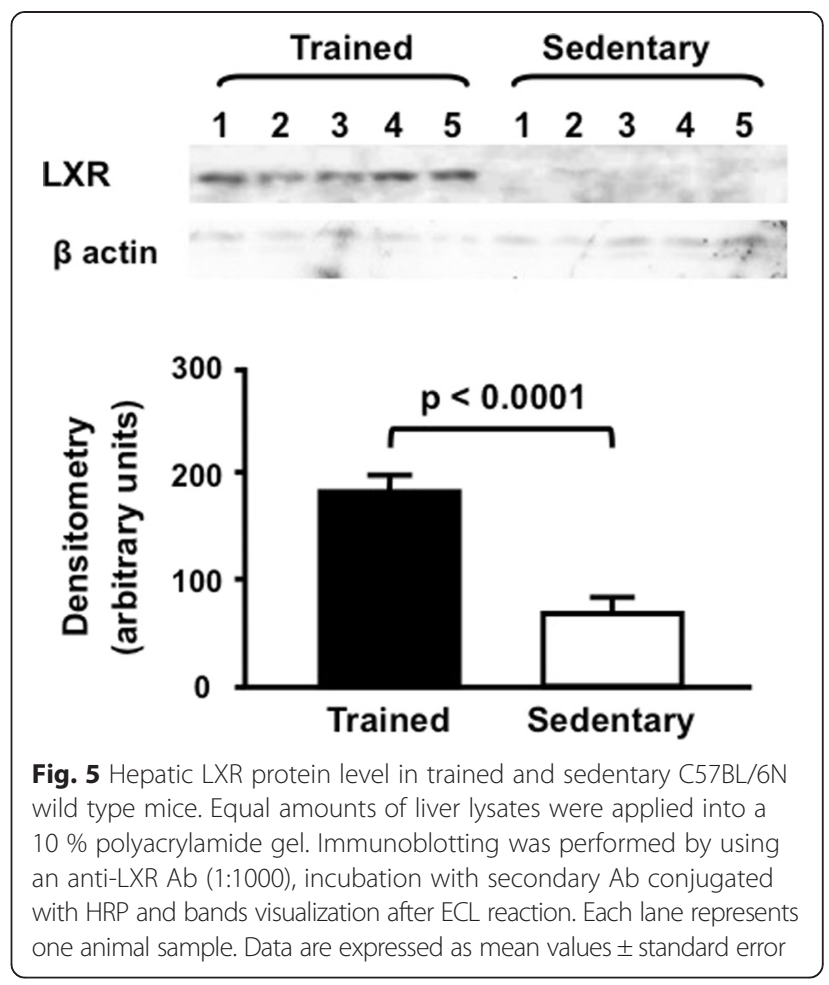

Il10 mRNA was increased in cells isolated after $48 \mathrm{~h}$ exercise session. $C c l 2$ and $I l 6$ were not changed when comparing sedentary and trained groups in cells isolated at $0 \mathrm{~h}$ and $48 \mathrm{~h}$ (Fig. $8 \mathrm{a}$ and b).

The ability of peritoneal macrophages isolated from sedentary and trained animals, after $48 \mathrm{~h}$ of the last exercise session, to export cholesterol to $\mathrm{HDL}_{2}$ or apo A-I was analyzed in in vitro incubations. The apo A-I and

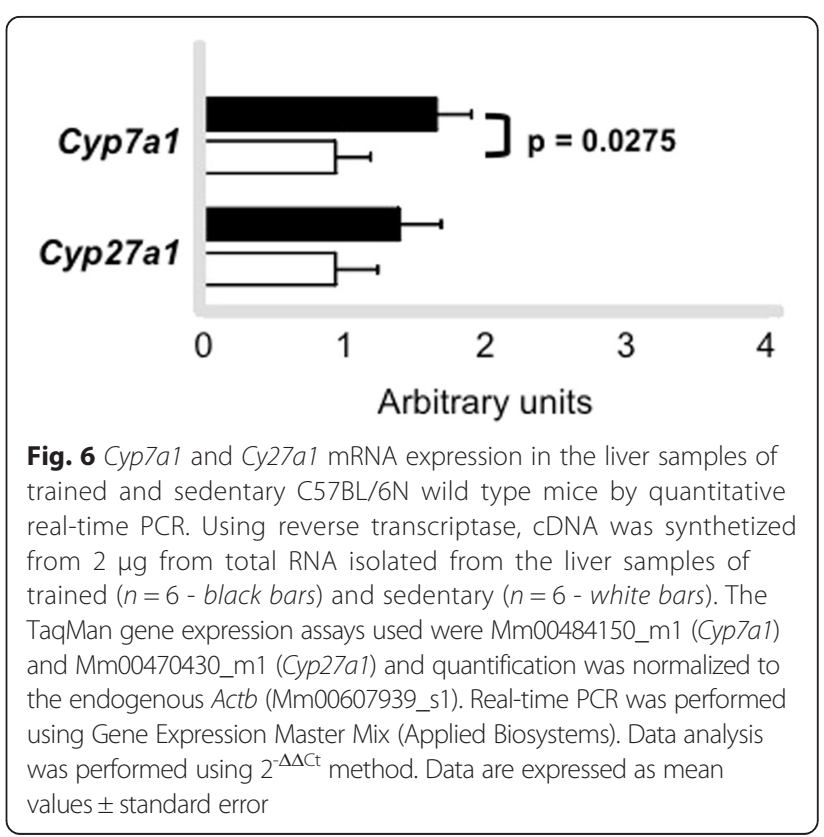




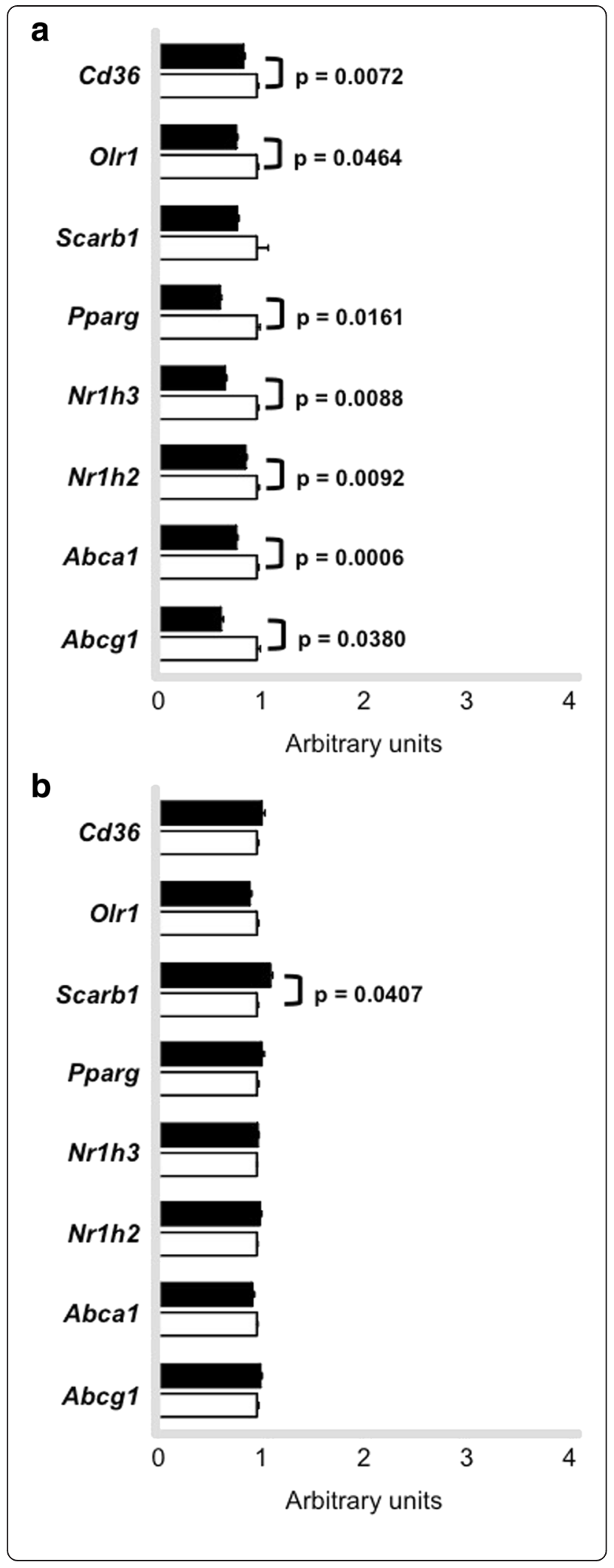

Fig. 7 Expression of genes involved in lipid flux in macrophages. Peritoneal macrophages were harvested from trained ( $n=6$ - black bars) and sedentary ( $n=6$ - white bars) C57BL/6N wild type animals immediately ( $0 \mathrm{~h}$ panel a) and $48 \mathrm{~h}$ (panel b) after the last exercise session. Macrophages were ressuspendend in Trizol and gene expression was determined by quantitative real-time PCR. Using reverse transcriptase, CDNA was synthetized from $100 \mathrm{ng}$ from total RNA isolated from macrophages of trained (black bars) and sedentary (white bars). The TaqMan gene expression assays used were: Cd36 - Mm0113519 8_m1, Olr1 Mm00454586_m1, Scarb1 - Mm00450234_m1, Pparg Mm01184322_m1, Nr1h3 Mm01329744_g1, Nr1h2 - Mm0043726 5_g1, Abca1 - Mm00442646_m1, Abcg1 Mm00437390_m1 and quantification was normalized to the endogenous Actb (Mm00607939_s1). Real-time PCR was performed using Gene Expression Master Mix (Applied Biosystems). Data analysis was performed using $2^{-\Delta \Lambda C t}$ method. Data are expressed as mean values \pm standard error

$\mathrm{HDL}_{2}$-mediated cholesterol efflux $(8 \mathrm{~h}$ and $24 \mathrm{~h}$ ) from macrophages was similar between groups (Fig. 9). Similarly, the uptake of ${ }^{3} \mathrm{H}-\mathrm{COE}$ by these cells was not changed by exercise (Fig. 10).

In aorta, as opposed to peritoneal macrophages, $C d 36$ and Orl1 mRNA were elevated at time $0 \mathrm{~h}$ but only Orl1 was kept high at 48 h. Scarb1 mRNA levels were not changed between groups in both periods of aortic arch isolation. $A b c a 1$ and $A b c g 1$ were not changed in aortas immediately isolated after exercise when comparing sedentary and trained groups. $A b c g 1$ mRNA was increased in aortic tissue isolated after $48 \mathrm{~h}$ of exercise bout in trained animals. Pparg and Nr1h3 mRNA were acutely elevated in cells by exercise in trained animals, although $\mathrm{Nr} 1 \mathrm{~h} 3$ was decreased in macrophages at $48 \mathrm{~h}$ (Fig. 11).

Tnf and IL6 mRNA levels were similar between sedentary and trained mice in both periods of aorta isolation. Il10 expression was decreased in trained mice in both periods ( $0 \mathrm{~h}$ and $48 \mathrm{~h}$ ) and $\mathrm{Ccl} 2$ was increased only in aorta isolated after $48 \mathrm{~h}$ of exercise session compared to sedentary animals (Fig. 12).

\section{Discussion}

Regular physical exercise improves lipid metabolism and contributes to the prevention of atherosclerosis. In this study, we investigated in wild type C57BL6N mice the role of a six-week aerobic exercise training program on the in vivo $\mathrm{RCT}$ and gene expression in peritoneal macrophages and aortic arch. Our results demonstrated that exercise training improves the recovery of ${ }^{3} \mathrm{H}$-cholesterol from peritoneal macrophages in plasma and liver, enhanced the hepatic expression of SR-BI, LXR and B-E receptor protein and increased the mRNA of Cyp7a1 in the hepatic tissue, independently of changes in gene expression in macrophages and aorta.

Wei $C$ et al. (2005) demonstrated that 2 weeks of aerobic exercise raises the mRNA of hepatic SR-BI in mice although in that paper authors did not determine the final protein content in the animal's liver [13]. SR-BI is known as 


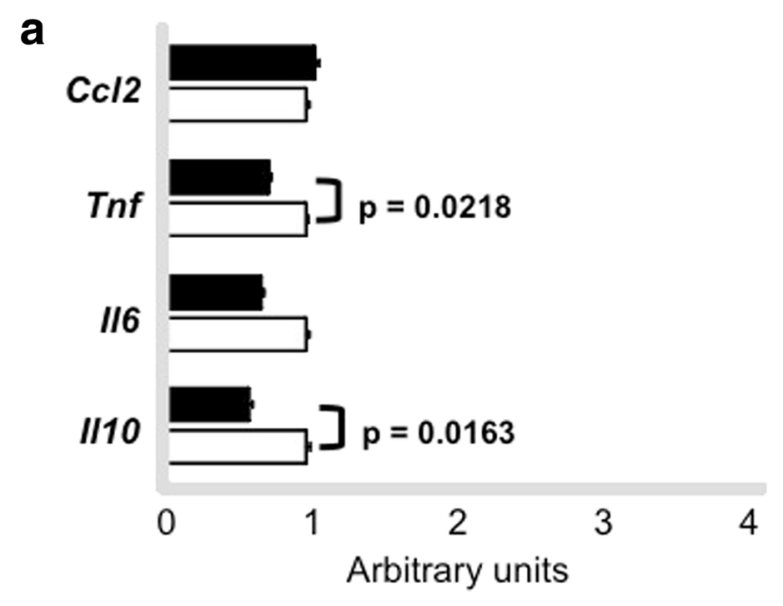

b

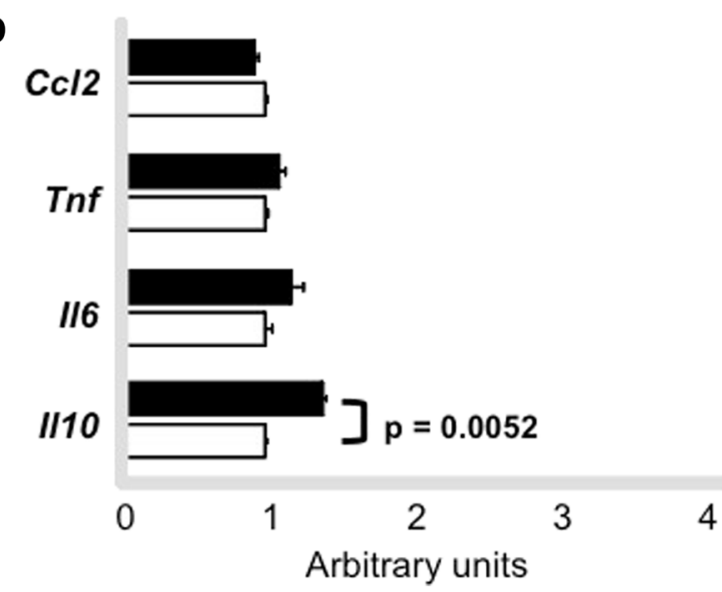

Fig. 8 Expression of genes involved in inflammatory response in macrophages. Peritoneal macrophages were harvested from trained $(n=6)$ and sedentary $(n=6)$ C $57 \mathrm{BL} / 6 \mathrm{~N}$ wild type animals immediately ( $0 \mathrm{~h}$ - panel a) and $48 \mathrm{~h}$ (panel b) after the last exercise session. Macrophages were ressuspended in Trizol and gene expression was determined by quantitative real-time PCR. Using reverse transcriptase, cDNA was synthetized from 100 ng from total RNA isolated from macrophages of trained (black bars) and sedentary (white bars). The TaqMan gene expression assays used were: C 12 Mm00441242_m1, Tnf - Mm00450234_m1, I/6 -Mm00450234_m1, I/10 Mm00450234_m1 and quantification was normalized to the endogenous Actb (Mm00607939_s1). Real-time PCR was performed using Gene Expression Master Mix (Applied Biosystems). Data analysis was performed using $2^{-\Delta \Delta C t}$ method. Data are expressed as mean values \pm standard error

an important regulator of the final step of the RCT, since it drives cholesterol for excretion into bile. In fact, SR-BI knockout mice besides having higher levels of plasma HDL cholesterol develop atherosclerosis [21]. On the other hand, SR-BI overexpression protects mice against diet-induced atherosclerosis despite of low HDL plasma levels [22]. In humans, SR-BI mutations lead to the impairment in its activity although has not been related to alteration in carotid intima-media thickness [23]. In our study the enhanced level of SR-BI expression contributed to a higher amount of ${ }^{3} \mathrm{H}$-cholesterol recovered in the liver of trained animals as compared to sedentary mice. Besides, the enhanced expression of this receptor may have masked the exercise-induced elevation in HDL cholesterol that has been described by others in rats and by our group in CETP-tg mice [24-26].

In accordance with previous data from literature [13, 27] we have shown an increased expression of hepatic LDL receptor (B-E). Nonetheless, in our animal model this receptor does not contribute to the last step of the RCT due to the absence of CETP.

In addition, the benefit of exercise training to the RCT was reflected by the elevated expression of Cyp $7 a 1$ mRNA, enzyme that converts free cholesterol into cholic acid the major route of bile acids synthesis. Surprisingly, we did not find differences in the ${ }^{3} \mathrm{H}$-cholesterol excretion into feces which may be ascribed to the experimental time points utilized (24 h and $48 \mathrm{~h}$ after ${ }^{3} \mathrm{H}$-cholesterol-labeled J-774 foam cells injection into peritoneal cavity). Also, we did not measure the $A b c g 5 / 8$ expression and excretion of bile acids and neutral lipids in feces which is a limitation of our study. In this regard, a recent investigation [28] demonstrated that in wild type mice, 12 weeks of voluntary running wheel modulated cholesterol catabolism by enhancing biliary bile acid secretion and increased fecal bile acid and neutral sterol outputs compared to sedentary controls.

In human CETP transgenic (CETP-tg) mice we previously showed [26] that aerobic exercise training improved $\mathrm{RCT}$ by increasing the recovery rate of macrophage ${ }^{3} \mathrm{H}$-cholesterol injected into peritoneal cavity in plasma and liver. Additionally, in this model we also found a higher amount of ${ }^{3} \mathrm{H}$-cholesterol in feces, completing the last step of the RCT. There were no changes in hepatic SR-BI content although a huge elevation was observed in B-E receptor protein level, bypassing cholesterol flux to the liver by the uptake of apo B-containing lipoproteins. In addition, compared to sedentary animals, trained CETP-tg mice presented higher levels of HDL-cholesterol in plasma and a higher ABCA1 content in the liver. These events were not observed in WT mice in the present investigation that presented similar levels of HDL cholesterol and no changes in the ABCA-1 protein levels. Together with the enhancement in $\mathrm{B}-\mathrm{E}$ receptor, this may explain why in CETP-tg mice we were able to observe an elevation in cholesterol excretion in feces that was not found in WT mice.

The expression of LXR a nuclear receptor that modulates the transcription of several genes involved in lipid metabolism, was increased by exercise in WT mice, although surprisingly we could not detect ABCA-1 in the liver of trained and sedentary mice.

A higher transference of radiolabed cholesterol from macrophages to plasma of trained animals observed by us in the in vivo analyses of the RCT cannot be attributed to enhancement in the cholesterol efflux rate. In 

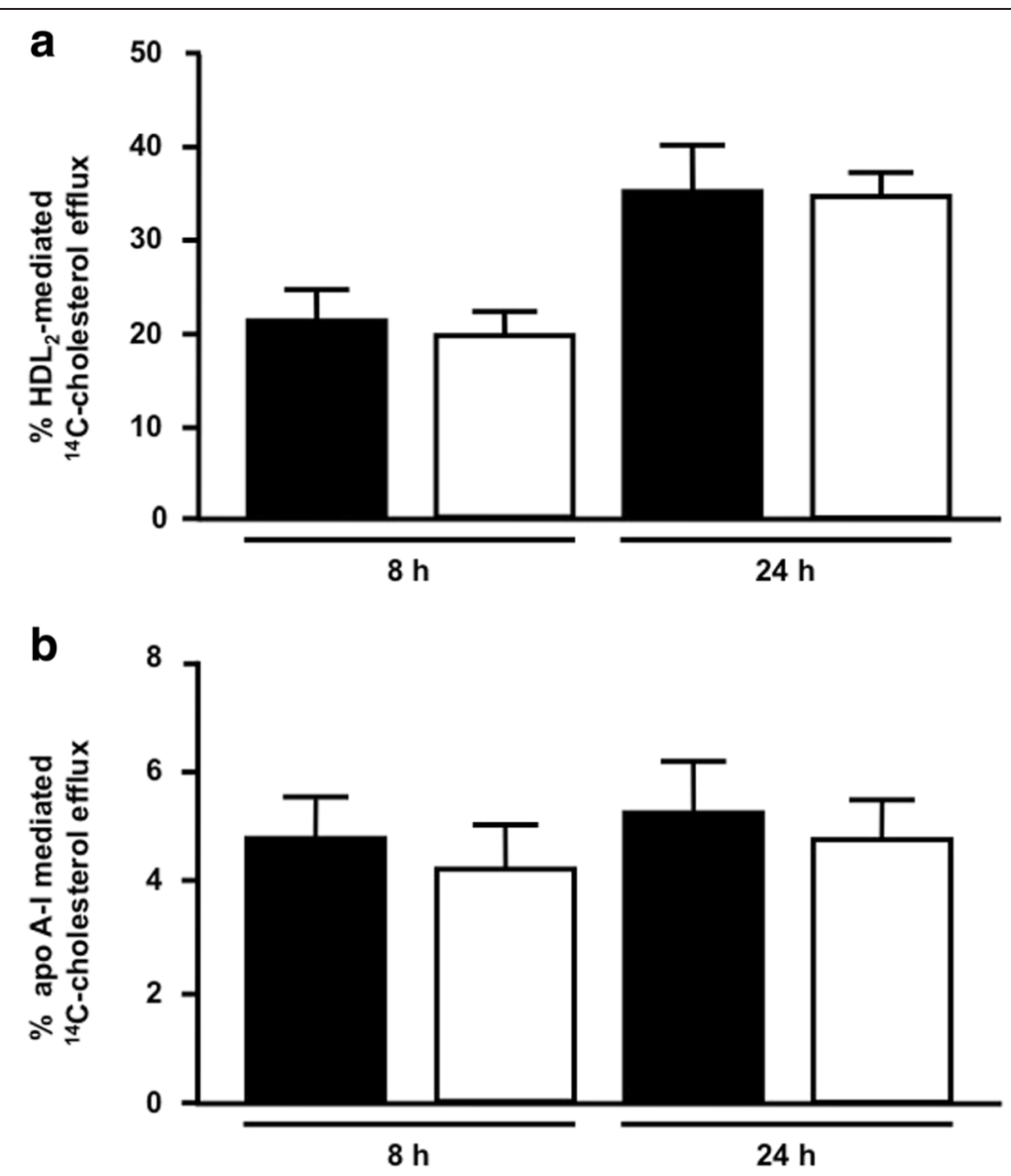

Fig. $9 \mathrm{HDL}_{2}$ and apo A-I mediated ${ }^{14} \mathrm{C}$-cholesterol efflux from peritoneal macrophages. Macrophages isolated from peritoneal cavity of trained $(n=7$ - black bars) and sedentary ( $n=7$ - white bars) C57BL/6N wild type mice, after $48 \mathrm{~h}$ the last exercise session, were enriched with acetylated LDL and ${ }^{14} \mathrm{C}$-cholesterol $30 \mathrm{~h}$. The ${ }^{14} \mathrm{C}$-cholesterol efflux was determined, after $8 \mathrm{~h}$ and $24 \mathrm{~h}$, of incubation with $\mathrm{HDL}_{2}$ (panel a) and apo A-I (panel b). ${ }^{14} \mathrm{C}$-cholesterol efflux was calculated as $\left({ }^{14} \mathrm{C}\right.$-cholesterol in the medium $/{ }^{14} \mathrm{C}$-cholesterol in cells plus medium $) \times 100$. Data are expressed as mean values \pm standard deviation

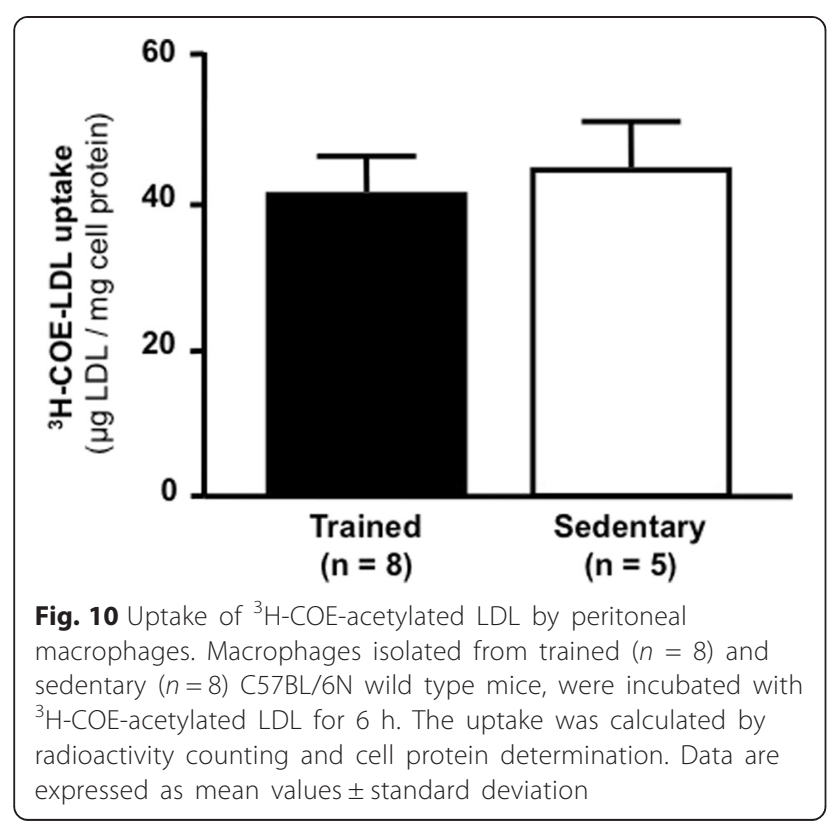

fact, no changes were observed in cholesterol efflux in macrophages isolated after $48 \mathrm{~h}$ of exercise session in trained as compared to sedentary animals. It is noteworthy that the expression of Abcal, Abcg1, Pparg, NrIh3 and Nr1h2 mRNA levels were acutely reduced by an exercise session but not after $48 \mathrm{~h}$ of exercise agreeing with the results of cholesterol exportation to apo A-I and $\mathrm{HDL}_{2}$. Scarb1 increased in macrophages from trained mice, although it did not interfere in cholesterol removal, considering that in macrophages overloaded with sterols, ABCA-1 is responsible for the major amount of cholesterol efflux to apo A-I. In addition, the alterations in inflammatory genes elicited by exercise did not affect cell cholesterol removal. In aorta, we did not find systematic changes in the expression of genes that modulate lipid flux, except for $A b c g 1$ at time $48 \mathrm{~h}$, suggesting that benefits elicited by exercise in the arterial wall site may not be totally related to the local modulation of RCT mediators.

The apparent discrepancy between the in vivo and in vitro experiments is probably related to the interplay of 


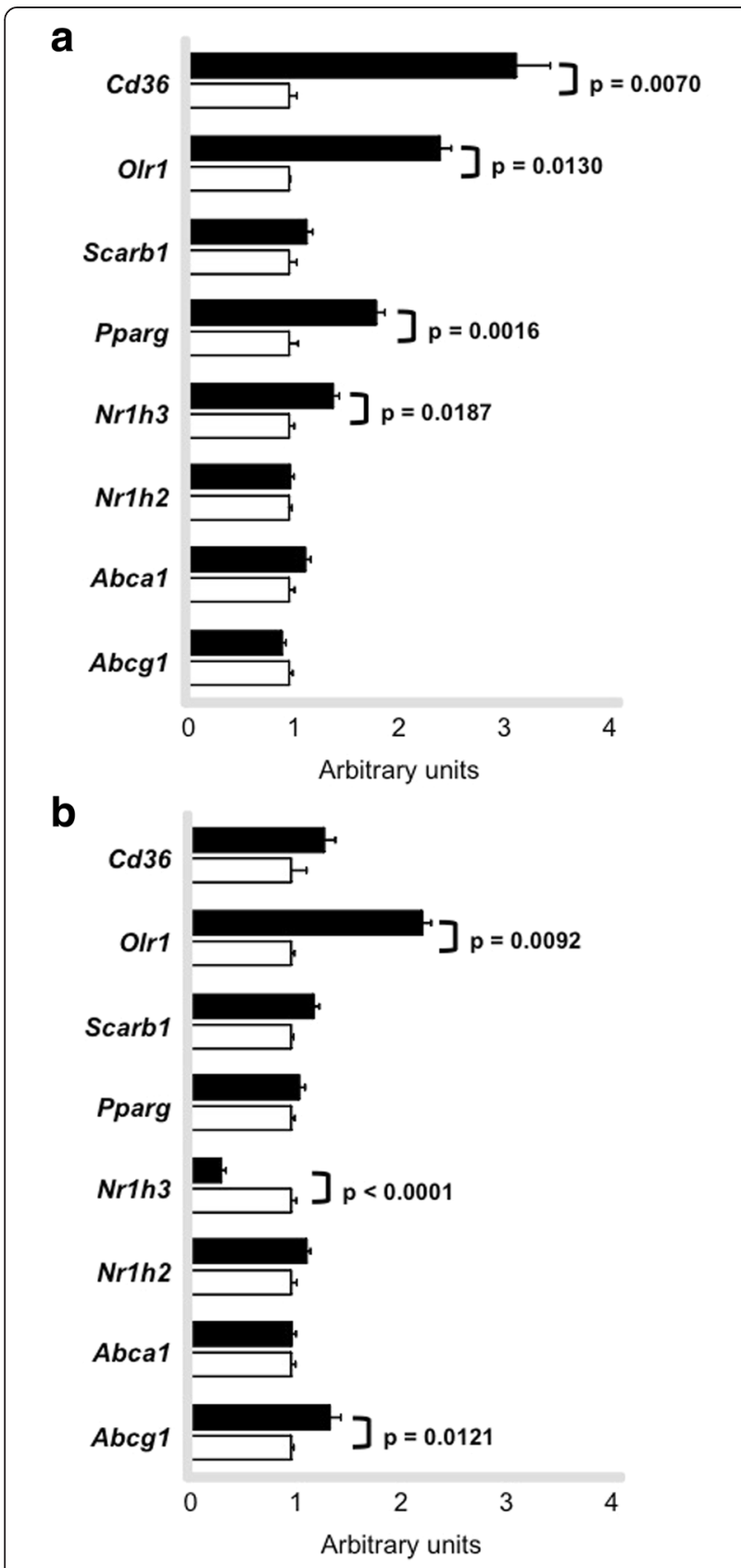

Fig. 11 Expression of genes involved in lipid flux in aorta. Aortic arch was isolated from trained $(n=7)$ and sedentary $(n=6)$ C57BL/6N wild type mice immediately $(0 \mathrm{~h}$ - panel a ) and $48 \mathrm{~h}$ (panel b) after the last exercise session. Gene expression was determined by quantitative real-time PCR. Using reverse transcriptase, CDNA was synthetized from $100 \mathrm{ng}$ from total RNA isolated from aortic arch of trained (black bars) and sedentary (white bars). The TaqMan gene expression assays used were: Cd36 - Mm01135198_m1, O/r1 Mm00454586_m1, Scarb1 - Mm00450234_m1, Pparg - Mm01184 322_m1, Nr1h3 Mm01329744_g1, Nr1h2 - Mm00437265_g1, Abca1 Mm00442646_m1, Abcg1 Mm00437390_m1 and quantification was normalized to the endogenous Gapdh (Mm99999915_g1). Real-time PCR was performed using Gene Expression Master Mix (Applied Biosystems). Data analysis was performed using $2^{-\Delta \Delta C t}$ method. Data are expressed as mean values \pm standard error

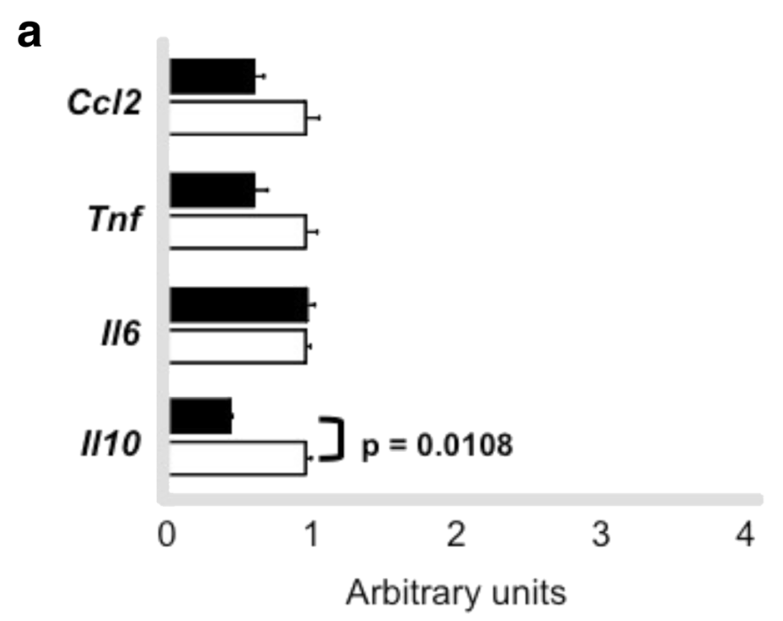

b

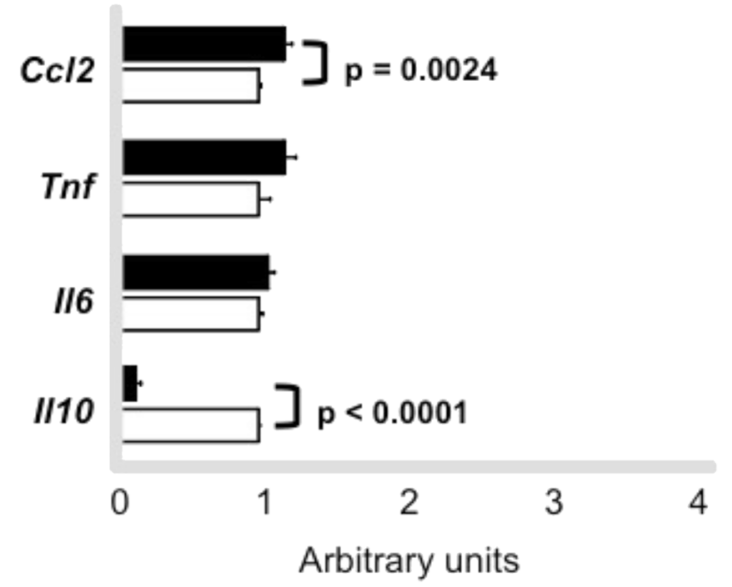

Fig. 12 Expression of genes involved in inflammatory response in aorta. Aortic arch was isolated from trained $(n=7)$ and sedentary $(n=7)$ C57BL/6N wild type mice immediately ( $0 \mathrm{~h}$ - panel a) and $48 \mathrm{~h}$ (panel b) after the last exercise session. Gene expression was determined by quantitative real-time PCR. Using reverse transcriptase, cDNA was synthetized from $100 \mathrm{ng}$ from total RNA isolated from aortic arch of trained (black bars) and sedentary (white bars). The TaqMan gene expression assays used were: Ccl2 - Mm00441242_m1, Tnf - Mm00450234_m1, II6-Mm00450234_m1, II10 - Mm00450234_m1 and quantification was normalized to the endogenous Gapdh (Mm99999915_g1). Real-time PCR was performed using Gene Expression Master Mix (Applied Biosystems). Data analysis was performed using $2^{-\Delta \Delta C t}$ method. Data are expressed as mean values \pm standard error

several components of the RCT that take place in vivo, including HDL levels, LCAT, lipoprotein lipase and hepatic lipase activities and receptors and enzymes that help to drive cholesterol to the liver. The in vitro experiments were designed in order to exclusively reflect possible cell changes induced by exercise in cell compartment. In that case, the concentration of HDL or apo A-I and physicochemical properties of these particles were unlikely to influence cell cholesterol removal. On the other hand, these variables were present in the in vivo experiments 
helping to drive cholesterol to the liver apart from specific changes in macrophage gene expression.

In conclusion, aerobic exercise training improves the cholesterol trafficking from macrophages to the liver in WT mice, which is related to the enhancement in hepatic SR-BI protein level together with a higher expression of Cyp7a1 and LXR, independently of systematic changes in macrophage and aorta gene expression. From the point of view of the RCT, the benefits of regular exercise in preventing atherosclerosis can be ascribed to an interplay of actions on systemic modulators of this transport, including HDL, and on the expression of hepatic and intestinal receptors that help to drive cholesterol from peripheral cell for excretion into feces.

\section{Competing interests}

The authors declare that they have no competing interests.

\section{Authors' contributions}

PRP carried out mice exercise training, biochemical analysis, macrophage efflux experiments, qRT-PCR, statistical analysis and participated in the manuscript preparation; DDFMR carried out animal exercise training, FPLC analysis and the in vivo reverse cholesterol transport experiments, statistical analysis and participated in preparation of the manuscript; LSO helped in the in vivo reverse cholesterol transport experiments; $A M L$ helped in mRNA analysis and statistics; GC, helped in efflux experiments and surgical procedures; KSS and DJG performed qRT-PCR; RSP performed western blotting analysis and helped in animal surgical procedures; RTI isolated plasma lipoproteins and performed the LDL uptake assays; GSF helped in animal care and training; ERN helped in statistics; UFM helped in data interpretation; MLCCG supervised qRT-PCR experiments and interpreted data; SC performed animal surgery and experimental design; MP was responsible for experimental design, coordination of research and preparation of themanuscript. All authors read and approved the final manuscript.

\section{Acknowledgements}

This work was supported by Fundação de Amparo à Pesquisa do Estado de Sao Paulo - FAPESP 12/04831-1 to MP, UFM and MLCCG; FAPESP 07/50387-8 to MP, 2011/15153-1 to PR, 06/52702-5 to DDFMRocco, 13/02854-7 to LS Okuda, 12/19112-0 to AML, 10/50108-4 to GC, $12 / 18724-2$ to KS, 11/04631-0 to DJG, $09 / 53412-9$ to RS Pinto; $12 / 12088-7$ to RTI, $14 / 07155$ to GF and by Conselho Nacional de Desenvolvimento Científico e Tecnológico (158314/ 2014-0 to DJG). The authors thank Prof. Shinji Yokoyama (Chubu University, Kasugai Japan) for providing us with apo A-I. The authors are indebted to Fabiana Ferreira for technical assistance; Walter Campestre and Antonio dos Santos Filho for caring for the animals. The authors are thankful to Fundação Faculdade de Medicina and Laboratórios de Investigação Médica (LIM).

\section{Author details}

'Lipids Laboratory (LIM - 10), University of São Paulo Medical School, Av. Dr. Arnaldo 455, room 3305, Sao Paulo, SP CEP 01246000, Brazil. 'Department of Physiology and Biophysics, Institute of Biomedical Sciences, University of Sao Paulo, São Paulo, Brazil. 'aboratory of Endocrinology and Cellular Metabolism (LIM - 25), University of São Paulo Medical School, São Paulo, Brazil.

Received: 21 April 2015 Accepted: 12 August 2015

Published online: 16 September 2015

\section{References}

1. Franklin BA, Durstine JL, Roberts CK, Barnard RJ. Impact of diet and exercise on lipid management in the modern era. Best Pract Res Clin Endocrinol Metab. 2014;28(3):405-21.

2. Kokkinos P. Cardiorespiratory fitness, exercise, and blood pressure. Hypertension. 2014;64(6):1160-4.
3. Ortega JF, Fernández-Elías VE, Hamouti N, Pallarés JG, Mora-Rodriguez R. Higher insulin-sensitizing response after sprint interval compared to continuous exercise. Int J Sports Med. 2015;36(3):209-14.

4. Kim B, Lee H, Kawata K, Park JY. Exercise-mediated wall shear stress increases mitochondrial biogenesis in vascular endothelium. PLoS One. 2014;9(11):e111409.

5. Womack CJ, Nagelkirk PR, Coughlin AM. Exercise-induced changes in coagulation and fibrinolysis in healthy populations and patients with cardiovascular disease. Sports Med. 2003;33(11):795-807.

6. Kannel WB, Wilson P, Blair SN. Epidemiological assessment of the role of physical activity and fitness in development of cardiovascular disease. Am Heart J. 1985;109(4):876-85.

7. Lee IM, Hsieh CC, Paffenbarger Jr RS. Exercise intensity and longevity in men. The Harvard Alumni Study. JAMA. 1995:273:1179-84.

8. Ramachandran S, Penumetcha M, Merchant NK, Santanam N, Rong R, Parthasarathy S. Exercise reduces preexisting atherosclerotic lesions in LDL receptor Knockout mice. Atherosclerosis. 2005;178:33-8.

9. Napoli C, Williams-Ignarro S, Nigris F, Lerman LO, D'Armiento FP, Crimi E, et al. Physical training and metabolic supplementation reduce spontaneous atherosclerotic plaque rupture and prolong survival in hypercolesterolemic mice. PNAS. 2006:13:10479-84.

10. Wang X, Rader DJ. Molecular regulation of macrophage reverse cholesterol transport. Curr Opin Cardiol. 2007;22:368-72.

11. Meissner M, Nijstad N, Kuipers F, Tietge UJ. Voluntary exercise increases cholesterol efflux but not macrophage reverse cholesterol transport in vivo in mice. Nutr Metab. 2010;7:54-8.

12. Meissner M, Havinga R, Boverhof R, Kema I, Groen AK, Kuipers F. Exercise enhances whole-body cholesterol turnover in mice. Med Sci Sports Exerc. 2010:42(8):1460-8.

13. Wei C, Penumetcha M, Santanam N, Liu GY, Garelnabi M, Parthasarathy S. Exercise might favor reverse cholesterol transport and lipoprotein clearance: Potencial mechanism for its anti - atherosclerotic effects. Biochim et Biophys Acta. 1723;2005:124-7.

14. National Research Council (US) Committee for the Update of the Guide for the Care and Use of Laboratory Animals. Guide for the Care and Use of Laboratory Animals, 8th edition. Washington (DC): National Academies Press (US); 2011.

15. Folch J, Lees M, Stanley S. A simple method for the isolation and purification of total lipids from animal's tissues. J Biol Chem. 1957;226:497-509.

16. Lowry OH, Rosenbrough NJ, Farr Al, Randal JR. Protein measurement with folin phenol reagent. J Biol Chem. 1951;193:265-75.

17. Basu SK, Goldstein JL, Anderson RGW, Brown MS. Degradation of cationized low density lipoprotein and regulation of cholesterol metabolism in homozygous hypercholesterolemia fibroblasts. Proc Natl Acad Sci. 1976;73:3178-82

18. Terpstra A, Nicolosi R, Hebert P. In vitro incorporation of radiolabeled cholesteryl esters into high and low density lipoproteins. JLR. 1989;30:1663-71.

19. Bustin SA, Mueller R. Real-time reverse transcription PCR (qRT-PCR) and its potential use in clinical diagnosis. Clin Sci (Lond). 2005;109(4):365-79.

20. Kubista M, Andrade JM, Bengtsson M, Forootan A, Jonák J, Lind K, et al. The real-time polymerase chain reaction. Mol Aspects Med. 2006;27(2-3):95-125.

21. Van Eck M, De Winther MP, Herijgers N, Havekes LM, Hofker MH, Groot PH, et al. Effect of human scavenger receptor class A overexpression in bone marrowderived cells on cholesterol levels and atherosclerosis in ApoE-deficient mice. Arterioscler Thromb Vasc Biol. 2000;20(12):2600-6.

22. Kozarsky KF, Donahee MH, Glick JM, Krieger M, Rader DJ. Gene transfer and hepatic overexpression of the HDL receptor SR-BI reduces atherosclerosis in the cholesterol-fed LDL receptor-deficient mouse. Arterioscler Thromb Vasc Biol. 2000;20(3):721-7.

23. Vergeer M, Korporaal SJ, Franssen R, Meurs I, Out R, Hovingh GK, et al. Genetic variant of the scavenger receptor Bl in humans. Engl J Med. 2011;364(2):136-45.

24. Khabazian BM, Ghanbari-Niaki A, Safarzadeh-Golpordesari A, Ebrahimi M, Rahbarizadeh F, Abednazari $\mathrm{H}$. Endurance training enhances ABCA1 expression in rat small intestine. Eur J Appl Physiol. 2009;107(3):351-8.

25. Ghanbari-Niaki A, Khabazian BM, Hossaini-Kakhak SA, Rahbarizadeh F, Hedayati M. Treadmill exercise enhances ABCA1 expression in rat liver. Biochem Biophys Res Commun. 2007;361:841-6.

26. Rocco D, Okuda L, Pinto R, Ferreira F, Kubo S, Nakandakare E, et al. Aerobic exercise improves reverse cholesterol transport in cholesteryl ester transfer protein transgenic mice. Lipids. 2011;46(7):617-25. 
27. Wilund KR, Feeney LA, Tomayko EJ, Chung HR, Kim K. Endurance exercise training reduces gallstone development in mice. J Appl Physiol. 2008;104(3):761-5.

28. Meissner M, Lombardo E, Havinga R, Tietge UJ, Kuipers F, Groen AK. Voluntary wheel running increases bile acid as well as cholesterol excretion and decreases atherosclerosis in hypercholesterolemic mice. Atherosclerosis. 2011;218:323-9.

Submit your next manuscript to BioMed Central and take full advantage of:

- Convenient online submission

- Thorough peer review

- No space constraints or color figure charges

- Immediate publication on acceptance

- Inclusion in PubMed, CAS, Scopus and Google Scholar

- Research which is freely available for redistribution 